\title{
PRELIMINARY BOUGUER ANOMALIES OF NORTH-EAST GREENLAND
}

\section{René Forsberg}

The geodetic survey of northern and north-eastern Greenland, executed by the Geodetic Institute, Copenhagen, was completed during the summer of 1980, when ground control for use in the photogrammetric mapping was established in the area from Kronprins Christian Land in the north to Bessels Fjord at $76^{\circ} \mathrm{N}$ on the east coast. As an integrated part of the survey operations, the establishment of the regional gravity network in northern Greenland, initiated in 1978 (Forsberg, 1979; Weng, 1980), was continued using two La Coste \& Romberg gravimeters. The heights of the gravity stations were determined using Doppler satellite positioning, triangulation or precise barometric levelling.

Preliminary Bouguer anomalies of the 1980 survey are shown together with some of the anomalies from the 1978 and 1979 surveys in fig. 33. No terrain corrections have been applied at present, as these will be calculated at a later stage when the digital terrain models to be used for the orthophoto map production become available. As many of the gravity stations are situated in very rugged topography the anomalies must be used with some caution, as the terrain corrections may increase the computed anomalies by $10 \mathrm{mgal}$ or more.

The most prominent feature of the Bouguer anomaly map is the decrease in the depth of the anomalies from the outer coast towards the Inland Ice. The highest recorded Bouguer anomaly is $+38 \mathrm{mgal}$ at the north east tip of Germania Land, and the lowest $-141 \mathrm{mgal}$ on a nunatak in southern Dronning Louise Land. A strong gravity gradient of up to $3 \mathrm{mgal} / \mathrm{km}$ runs more or less parallel to the outer coastline, forming an apparent continuation of a similar gradient observed along the north coast of Greenland. The gradient is probably due to a rather abrupt change in crustal thickness between the land area and the continental shelf, in accordance with general principles of isostatic equilibrium and experience from other continent/shelf transition areas.

Inland from the outer coast the anomalies decrease, forming a vague gravity minimum trend from Wandel Hav in the north to Dronning Louise Land in the south. The coast-parallel gravity minimum belt seems to be a more or less general phenomena of the Greenland coasts, and is especially well-developed along the north coast from Hall Land to Peary Land, where it probably reflects to a high degree the effect on the North Greenland Lower Palaeozoic sedimentary basin. In north-eastern Greenland, on the other hand, it is probably more or less a pure glacio-isostatic phenomena, as the lowest anomaly values to the south also correspond to the areas of highest elevation. An exeption may be over Wandel Hav to the north, where the broad, but shallow, relative gravity minimum correlates fairly well with the expected deepest part of the, mainly Mesozoic, Wandel Sea sedimentary basin.

In the inner parts of the wide, ice-free area from Kronprins Christian Land to Peary Land the Bouguer anomalies are generally somewhat higher than would be expected from isostatic considerations. In this broad positive residual anomaly region, smaller, poorly defined, anomalies are superimposed: a positive anomaly, possibly trending NW-SE, is centered to the north-west of Hagen Fjord and may be related to the basalts of the area; around 


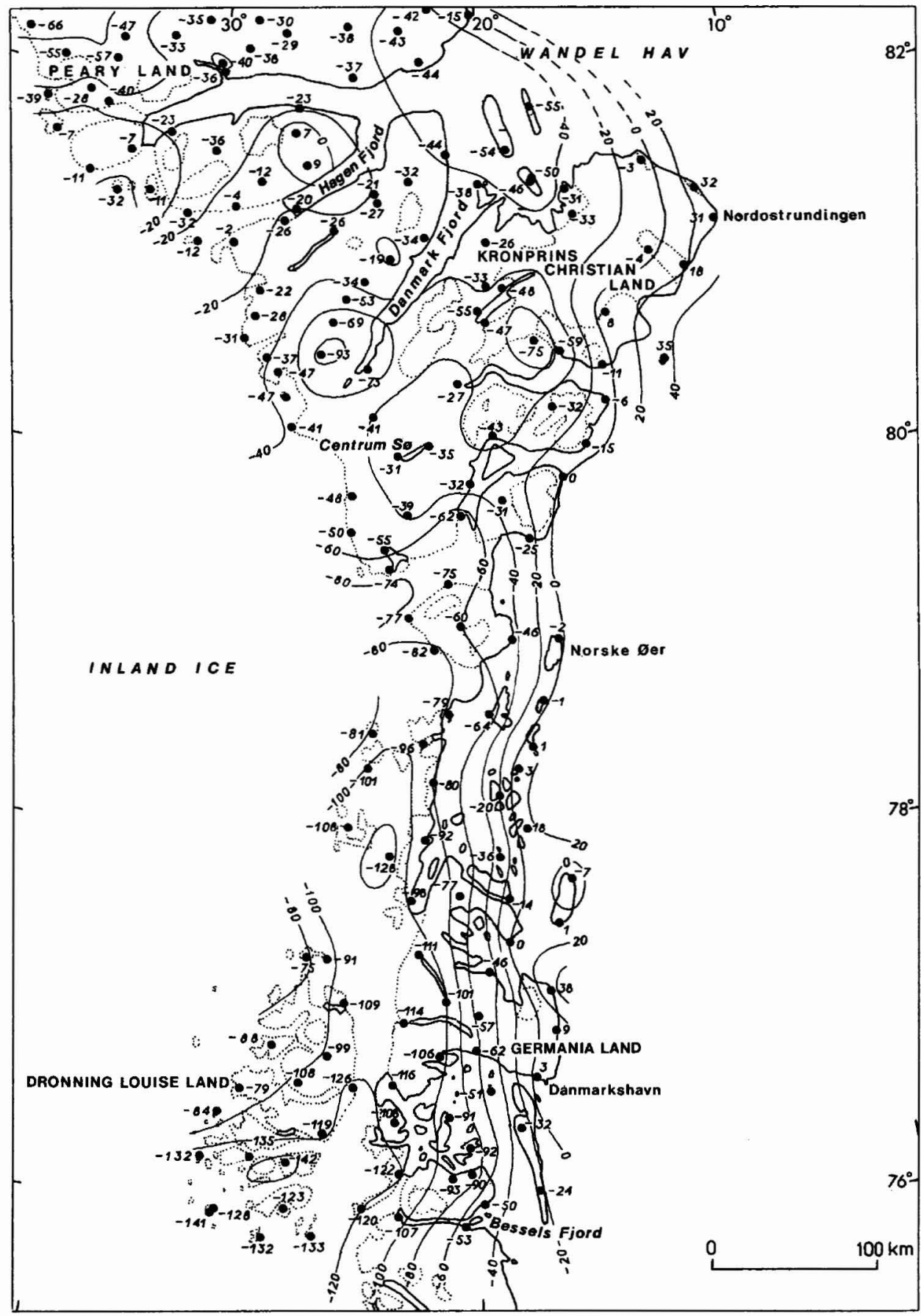

Fig. 33. Bouguer anomaly map of north-eastern Greenland. Contour interval 20 mgal, density 2.67 $\mathrm{g} / \mathrm{cm}^{3}$, datum IGSN71, reference GRS67, no terrain corrections. The outline of the coast and the ice-margin are based on the correct geodetic positions for the gravity stations, and the map is therefore free of the serious distortions affecting older maps of the area. 
Centrum Sø there seems to be a broad residual high; and near the south end of Danmark Fjord a large negative residual anomaly is apparent. Interpretation of these and similar features of the rough-resolution Bouguer map will naturally be highly speculative, unless other types of geophysical information can be utilized.

\section{References}

Forsberg, R. 1979: A gravity map of Peary Land, North Greenland. Rapp. Grønlands geol. Unders. 88, 93-94.

Weng, W. L. 1980: Preliminary Bouguer anomalies of western North Greenland. Rapp. Grønlands geol. Unders. 99, 153-154. 